\title{
Human Will, Human Dignity, and Freedom: A Study of Giorgio Benigno Salviati's Early Discussion of the Will, Urbino 1474-1482
}

\author{
Amos Edelheit \\ De Wulf-Mansion Centre, Katholieke Universiteit Leuven
}

\begin{abstract}
This article presents the first detailed account of Giorgio Benigno Salviati's discussion of the will written in Urbino during the mid-1470s and the early 1480s. A Franciscan friar and a prominent professor of theology and philosophy, Salviati was a prolific author and central figure in the circles of Cardinal Bessarion in Rome and of Lorenzo de' Medici in Florence. This article focuses on his defense of the Scotist theory of the will. It considers its fifteenth-century context, in which both humanist and scholastic thinkers dealt with the question of the intellect and the will. While basing himself partly on authorities such as Aristotle, Augustine, and Thomas Aquinas, Salviati is clearly aware of the novelty of his theory, and its important implications for ethics and theology.
\end{abstract}

\section{Keywords}

Intellect, will, humanism, scholasticism, Salviati, Ficino

While the Italian humanists of the fifteenth century have been the object of many detailed studies, their scholastic contemporaries have been relatively neglected in modern scholarly literature. ${ }^{1}$ Though there is still much more

\footnotetext{
1) This point is most evident in the works of the two greatest historians of Renaissance thought in the twentieth century, Eugenio Garin and Paul Oskar Kristeller. While Garin emphasized the importance and novelty of "the philosophy of non-philosophers", thus contrasting the humanists and the scholastics, e.g., in his Medioevo e Rinascimento (Bari, 1954; reprinted Bari, 1973), 38-39, Kristeller tried to exclude the humanists from most of the philosophical disciplines, which he identified with the scholastics; see, e.g., his 'Florentine Platonism and its Relations with Humanism and Scholasticism', in Church History 8 (1939), 201-211, reprinted in his 
work to be done on humanist thinkers, especially with regard to the editing of many texts which are still available only in manuscript form, ${ }^{2}$ the corpus of fifteenth-century scholastic thinkers is generally ignored. The prevailing assumption that scholasticism underwent a serious decline at the end of the thirteenth century has no doubt affected scholarly opinion, and the humanists have been regarded as able critics of this declining philosophical discourse, thus offering new methods and modes of thought which have been connected with the dawn of modernity. There is no doubt that some humanists were very critical towards scholastic philosophical discourse but we should be more cautious with regard to the sharp dichotomies underlining historiographical assumptions. ${ }^{3}$ We should first realize that we are still quite far from a clear and detailed picture of the scholastic philosophy in the fifteenth century. Thus, for instance, terms like 'Thomism' and 'Scotism' must receive careful definitions in different historical contexts before we are in a position to make more

Studies in Renaissance Thought and Letters III (Roma, 1993), 39-48; see especially p. 40, and his Renaissance Thought and its Sources, ed. Michael Mooney (New York, 1979), p. 23. Although Kristeller stressed the importance of detailed studies of fifteenth-century "religious literature", e.g., in his 'Lay Religious Tradition and Florentine Platonism', in Studies in Renaissance Thought and Letters (Roma, 1969), 99-122, see p. 121, he dedicated most of his studies to Ficino and Renaissance Platonism, and to the humanists. His accounts of fifteenth-century scholasticism are usually very general, and much depended upon the conceptual paradigm of Gilson, e.g,.., his 'Thomism and the Italian Thought of the Renaissance', in Medieval Aspects of Renaissance Learning, ed. and trans. Edward P. Mahoney (Durham, NC, 1974), 29-91. For the lacuna in modern scholarship regarding fifteenth-century scholastic thinking see, e.g., the remarks on 47-48, 5253, 55-57. For a critique of this conceptual paradigm, mainly with regard to the intellectualistsvoluntarists controversy', see Martin F.W. Stone, 'Moral Psychology After 1277. Did the Parisian Condemnation Make a Difference to Philosophical Discussions of Human Agency?', in Jan A. Aertsen, Kent Emery, Jr. and Andreas Speer (eds.), Nach der Verurteilung von 1277. Philosopie und Theologie an der Universität von Paris im letzten Viertel des 13. Jahrhunderts. Studien und Texte (Berlin, 2001), 795-826; see 809 and 826; for references to the works of Ehrle, Mandonnet, and Gilson, see 795-796, n. 2. See also Stone's critical remarks in his 'The Origins of Probabilism in Late Scholastic Moral Thought: A Prolegomenon to Further Study', in Recherches de Théologie et Philosophie médiévales LXVII, 1 (2000), 114-157; see n. 35 on 126-127. For Kristeller's important discussion of Vincenzo Bandello see $\mathrm{n}$. 5 below.

2) This point was emphasized recently by Christopher S. Celenza in his The Lost Italian Renaissance-Humanists, Historians, and Latin's Legacy (Baltimore, 2004), especially in the introduction and in chapter one, for the humanists.

3) For some general remarks on traces of Thomas' work left in the writings of Italian humanists and some critical accounts of Thomas and Thomists see Kristeller, 'Thomism and the Italian Thought', 59-91. One should note, however, that humanist thinkers like Petrarch, Salutati, Bruni, Ficino, and Pico for instance, each represents different attitudes towards scholastic philosophy. 
general assessments about such terms. We should also reexamine the complicated relations between humanist philosophers and scholastic philosophers, since, beyond the obvious differences there are important mutual influences, both in style and contents, between these two groups of intellectuals. My basic argument here is that without such reexamination of the relations between humanists and scholastics, we shall not have a balanced and reliable picture of the intellectual history in the fifteenth century.

In the present article I intend to offer a detailed study of an early work by the Franciscan philosopher and theologian Giorgio Benigno Salviati (c. 14481520) on the importance of the will in the human soul. ${ }^{4}$ This philosophical issue which is of course related to an established question in medieval philosophy regarding the two dominant faculties in the human soul-the intellect and the will —often regarded as the dispute between the 'intellectualists' (usually identified as 'Thomists') and the 'voluntarists' (usually identified as 'Scotists'), seems to have acquired a new dimension in the fifteenth century.' Salviati himself has already been a subject of debate among some historians, regarding the question of whether he should be classified as a humanist or as a

4) This early discussion, written in dialogue form during Salviati's stay in Urbino some time between 1474 and 1482, and entitled Fridericus, On the Prince of the Soul's Kingship, can be found in P. Zvonimir Cornelius Šojat O.F.M., De voluntate hominis eiusque praeeminentia et dominatione in anima secundum Georgium Dragisic (c. 1448-1520), studium historico-doctrinale et editio Tractatus: 'Fridericus, De animae regni principe' (Roma, 1972), 139-219; for a biographical sketch and a list of Salviati's works see 27-63; a doctrinal study of the dialogue can be found on 69-128. For a more detailed biographical sketch and an intellectual profile, see Cesare Vasoli, Profezia e ragione. Studi sulla cultura del Cinquecento e del Seicento (Napoli, 1974), 17-127. See also Vasoli's Filosofia e religione nella cultura del Rinascimento (Napoli, 1988), 139-182, for a detailed account of Salviati's Scotist commentary on Lorenzo de' Medici's sonnet. For another work by Salviati which is critically edited, on future contingencies, see Girard J. Etzkorn (ed.), De arcanis Dei. Card. Bessarion eiusque socii anno 1471 disputantes: card. Franciscus de la Rovere OFM Conv, Joannes Gattus OP, Fernandus de Cordoba et Joannes Foxal OFM Conv. Secretarius: Georgius Benignus Salviati OFM Conv. (Rome, 1997).

5) In the course of this article I shall be referring to a dispute between Marsilio Ficino and Lorezo de' Medici, and to the critical account of Ficino's part by Vincenzo Bandello, on the intellect and the will. For a more detailed account of this dispute see Kristeller, 'A Thomist Critique of Marsilio Ficino's Theory of Will and Intellect', in Harry Austryn Wolfson Jubilee Volume, English section vol. II (Jerusalem, 1965), 463-494. See also my 'Vincenzo Bandello, Marsilio Ficino, and the Intellect/Will Dialectic', in Rinascimento [forthcoming]. For another discussion of the same topic by a young student of Ficino, Alamanno Donati, see his De intellectus voluntatisque excellentia, which was written between 1482-1487, edited and published by Lambertus Borghi, in Bibliofilia XLII (1940), 108-115. Elsewhere I hope to present a detailed account of this text. 
scholastic thinker. ${ }^{6}$ Such a debate is already an indication of Salviati's unique historical position in the intellectual history of Italy in the last three decades of the fifteenth century and in the first two decades of the sixteenth century. I hope that the present discussion will offer a contribution to the study of fifteenth-century scholasticism and to the assessment of the relations between the humanists and the scholastics of that period.

Giorgio Benigno Salviati (or in his original name Juraj Dragišić) was born in Srebrenica in Bosnia in the late 1440s, and joined the conventual Franciscans. After the Turkish conquest in 1463 he moved to Ragusa (Dubrovnik), and then on to Italy, where he studied in the studia of his order in Padova, Pavia, and Ferrara, finally residing in Paris and in Oxford. He was trained in scholastic philosophy, and he especially mentions one of his teachers, Joannes Foxoles (1415/6-1475), an English theologian and philosopher in the Scotist tradition. ${ }^{7}$ We then find Salviati in the circle of Cardinal Bessarion in Rome in the early 1470s, at the court of Federico of Montefeltro in Urbino between 1472 and 1482, in Florence of Lorenzo de' Medici from around 1486 until 1494. Then, after a short period in Ragusa, he returned to Rome in 1500, becoming bishop of Cagli in 1507, and finally the archbishop of Nazareth in 1512. He died in Rome in 1520. During his long career, Salviati played a leading role in many theological and philosophical debates (e.g., Bessarion vs. George of Trebizond and the controversy regarding future contingencies in Rome, or the debate on evil and the Savonarola affair in Florence, as well as the Reuchlin affair), while teaching theology and philosophy, preaching, and writing many texts. ${ }^{8}$

As already mentioned (see n. 4) Salviati's discussion of the will which we are about to examine was written, like most of his works, in dialogue form. This

\footnotetext{
6) See the critical remarks of Carlo Dionisotti against François Secret in 'Umanisti dimenticati?', in Giuseppe Billanovich, Augusto Campana, Carlo Dionisotti, and Paolo Sambin (eds.), Italia medioevale e umanistica IV (1961) (Padova 1961), 287-321; see e.g., 287-292. We may point out that most of Salviati's texts have not yet been critically edited, some are still available only in manuscript form, there are hardly any detailed discussions of them, and we do not have yet a full modern biography of this author.

7) On Foxoles see e.g., with further references, Girard J. Etzkorn, 'John Foxal, O.F.M.: His Life and Writings', in Franciscan Studies 49 (1989), 17-24; Lorenzo Di Fonzo, 'Il minorita inglese Giovanni Foxholes. Maestro scotista e arcivescovo (ca. 1415-1475)', in Miscellanea Francescana 99/I-II (1999), 320-346.

8) Vasoli, Profezia e ragione, e.g., 21-28, 35-39, 57, 83-85, 100, 109, 117-120, with further references.
} 
fact might suggest already a humanistic influence upon our Franciscan friar. ${ }^{9}$ But it is important to stress that Salviati was by no means unique in choosing this literary form for his speculative treatises. In the second half of the fifteenth century we possess a considerable number of dialogues written by scholastic thinkers. (On the other hand, humanist thinkers like Ficino and Pico did not write dialogues.) I would contend that this fact reflects not only some influence of the humanists upon the scholastics, but also an internal development in late-scholastic philosophical style. But we need many more detailed accounts of such texts and their contexts before we can reach some more general conclusions about this stylistic development. ${ }^{10}$

Salviati's dialogue Fridericus, On the Prince of the Soul's Kingship was written during his sojourn at Urbino, and it is dedicated to Guidubaldo, the son of Federico, duke of Urbino. ${ }^{11}$ The two interlocutors in the dialogue are Fridericus, who represents Salviati's own account of the superiority of the will, and his close friend Octavianus (Ottaviano Ubaldini), who argues for the superiority of the intellect. After a short proem, each of the participants in the dialogue

9) This point was already emphasized by Dionisotti in his 'Umanisti dimenticati?' 301-303, 314-315.

10) Some examples are Antonio degli Agli's De mystica statera, a dialogue between himself and Ficino, who was his student, in which "Antonius exhorts Fecinus to remember that Christian studies are to be placed before pagan studies", a text which still remains in manuscript: MS Naples BN VIII. F. 9, ff. 19-33; see Celenza, Piety and Pythagoras in Renaissance Florence-The Symbolum Nesianum (Leiden, 2001), p. 27 and nn. 99 and 100 there. Another professional theologian who was one of Ficino's early teachers, Lorenzo Pisano, wrote three dialogues, probably between the late 1450s and the early 1460s, entitled: Dialogi humilitatis, De amore, and Dialogi quinque, which are still in manuscripts; see Arthur Field, The Origins of the Platonic Academy of Florence (Princeton, 1988), 158-174, see especially p. 162, and 277-279. Another example is Francesco di Tommaso, a Dominican of Santa Maria Novella, who in 1480 wrote a dialogue De negocio logico, which he dedicated to Poliziano, and in which he attempted to explain the problem of universals as presented in Prophyry's Isagoge. See Jonathan Hunt, Politian and Scolastic Logic: An Unknown Dialogue by a Dominican Friar (Città di Castello, 1995). I am now preparing an editio princeps of yet another dialogue by a Dominican theologian, the Liber dierum lucensium (1461/2) by Giovanni Caroli. On the revival of the Ciceronian dialogue in the Renaissance see David Marsh, The Quattrocento Dialogue: Classical Tradition and Humanist Innovation (Cambridge, MA, 1980). But this revival of the dialogue form by professional scholastic theologians in the last decades of the fifteenth century still needs to be studied.

11) Salviati, Fridericus... p. 139: "Georgii Benigni, Ordinis Minorum, sacrae theologiae professoris, in Fridericum, De animae regni principe, ad optimae indolis maximaeque spei puerum dominum Guidonem Ubaldum, comitem, prooemium incipit feliciter." Some general details on this text can be found in Vasoli, Profezia e ragione, 35-39. 
presents his general thesis (chapters 1-2), then Octavianus presents more detailed arguments for the superiority of the intellect (chapters 3-7), and then, Fridericus presents his case for the superiority of the will, and its importance for ethics and theology (chapters 8-21). The last part (chapters 22-24) contains a refutation of Octavianus' arguments. Let us now move on to a more detailed account of the dialogue and its philosophical context.

While in Ficino's dispute with Lorenzo de' Medici and Vincenzo Bandello regarding the will and the intellect, which was held in 1474, both the term and the notion of libertas are missing, his emphasis is on amor and on being or becoming good through the power of the will in contrast to merely knowing what is good through the power of the intellect. Salviati's discussion also contains some similar arguments regarding the role of amor and the function of the will. ${ }^{12}$ But, as we shall see in the present discussion, in contradiction to Ficino, Salviati emphasizes libertas as the quality of the human will per se, and his discussion of libertas anticipates his discussion of liberum arbitrium, in which we find the standard distinction between arbitrium rationis and arbitrium voluntatis. Only the latter is related to libertas through the will. At first sight, what we have here is a richer philosophical account than Ficino's letter on the human will and its importance to human life, to ethics and to theology, in which both Thomas Aquinas and John Duns Scotus, as well as Aristotle (among other ancient and medieval thinkers) are used as authorities.

In chapter 12, entitled: quod homo magis distet a beluis voluntate quam intellectu voluntasque ea ratione sit praestantior, Salviati states that the will is what gives preeminence in nature to man. The will is contrasted to nature, to the

12) Ficino's part in this dispute is included in his letter to Lorenzo entitled: Quid est felicitas, quod habet gradus, quod est eterna, in Opera omnia, 2 vols. (Torino, 1962), vol. 1, 662-665; I shall refer here to the critical edition in: Lettere I-Epistolarum familiarium liber I, ed. Sebastiano Gentile (Firenze, 1990), 201-210; see e.g., p. 205: “... quemadmodum deterius est odisse Deum quam ignorare, sic melius amare quam nosse”; p. 206: “... et sicut non qui videt bonum, sed qui vult fit bonus, sic animus non ex eo quod Deum considerat, sed ex eo quod amat fit divinus, quemadmodum materia non quia lucem ab igne capiat, sed quia calorem, ignis evadit"; p. 207: "Quod cum multo plures amare Deum ardenter possint quam clare cognoscere, amatoria via et hominibus tutior est, et ad infinitum bonum, quod se ipsum vult quam plurimis impertire, longe accomodatior: ad voluntatem igitur pertinet consecutio." Compare with Salviati, Fridericus, p. 167: "Actus vero voluntatis est amor sive odium; at veluti voluntas non intelligit, ita nec intellectus amat: si enim non essent actus distincti, neque potentiae distinguerentur; sed distinctae sunt potentiae; neque igitur intellectus amorem, neque voluntas intellectionem producet”; p. 169: “...quia veluti scire ita et iudicare bonum non facit nos esse bonos, sed id acceptare et velle." 
senses and to the intellect; it is a dominant, active, and ruling element which is free. The intellect, on the other hand, is not peculiar to man:

Since every living being understands, and understanding, in turn, is the genus of reason and sense-perception; therefore, the intellect falls [i.e., as a species] under the same genus as the sense; since all these are defined as 'apprehensive powers' and they are all natural principles. But only the will differs from them as to their common genus, and only the will is separated from, and opposed to them, and is called active by its own intention, that is, free.

... but only the will is by itself free, reason is no more than vision; and thus man, while acting through his intellect, just like acting through his sense, is acting according to nature. Only [while acting] through his will, [just] as a free agent, man chiefly separates himself from beasts. But the more man separates himself from beasts, he becomes more man; therefore, this thing will be more noble, through which he is most removed from the baser things. And thus the will, when man would be seen at his most human, should be regarded as the most excellent element in man. ${ }^{13}$

Salviati, the prominent Franciscan theologian and philosopher, the spiritual heir of Cardinal Bessarion who later played such a leading role in Lorenzo de' Medici's circle in Florence, is making here his own important contribution to fifteenth-century discussions of the dignity of man, a theme which is usually related to the humanist movement. ${ }^{14}$ Salviati is thus rejecting the idea

13) Salviati, Fridericus p. 173: "Omne enim animal cognoscit, cognitio quoque genus est ad rationis sensusque notitiam; intellectus igitur cum sensu sub eodem genere cadit. Vocantur enim omnes 'potentiae apprehensivae', suntque cunctae naturales causae. At sola voluntas ab eis quovis eis communi genere differt, solaque e contra dividitur, vocaturque agens a proposito sive liberum"; "... sola vero voluntas ex se libera est, ratio non magis quam visus; homo itaque per intellectum agit natura, sicut et per sensum. Sola voluntate, tamquam libero agente, a beluis potissime distat; quo vero magis distat, eo magis est homo; magis igitur id erit nobile, quo maxime a vilioribus removetur. Voluntas itaque cum maxime homo videatur, 'praestabilissimum quid' in homine sit fatendum est." On this see also the general remarks of Vasoli in his Profezia e ragione p. 36 .

14) While dealing with a historical figure like Salviati, one cannot use too strict or schematic definitions of humanism or scholasticism (on this issue see the remarks and references in n. 1 above, as well as Dionisotti's remarks referred to in n. 6 above. For one such too strict and very influential approach to the humanist movement, see Ronald G. Witt, 'The Humanism of Paul Oskar Kristeller', in John Monfasani (ed.), Kristeller Reconsidered. Essays on his Life and Scholarship (New York, 2006), 257-267; see especially 258-259. Rather, we need a more flexible and dynamic notion, in which also the Franciscan friar who was so active in the intellectual and religious life in Rome and Florence, for instance, and had close relations with prominent figures of the time in both Cardinal Bessarion's circle (Fernando di Córdoba, Giovanni Gatto, Cardinal and the future pope Francesco della Rovere, and Salviati's teacher John Foxoles) and in Lorenzo de' Medici's circle (Ficino and Pico among many other humanists and scholastics), could be 


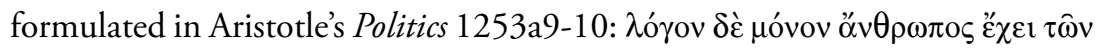
$\zeta \omega \omega v$, an idea that became so central among the later ancient and medieval Greek, Latin, and Arab interpreters, and was so dominant in many contexts of scholastic philosophy. He also rejects Augustine's notion of rationalis anima as what gives preeminence in nature to man. ${ }^{15}$ While his solution is quite different from Ficino's, who, in his De Christiana religione of 1474, regarded religion as most characteristic of man and of human society and culture, it is in a way closer to Pico's famous treatment of this theme in the opening lines of his oration of 1486, later entitled De hominis dignitate, in which man received from God the possibility to choose his own fate and way of life. ${ }^{16}$ But Salviati, on

adequately studied. Though he was "only" a theologian and a philosopher who studied in Paris and Oxford, and not strictly a philologist, his social and intellectual involvement placed him inside the humanist milieu. It is enough to mention here his defense of Pico or Reuchlin, but also of Savonarola, in order to show the historical complexity we have to deal with. My point is not that we should turn Salviati into a humanist, but rather that we should use more sensitive historical terms through which we would be able to follow him through the different historical contexts in which he was active.

15) Augustine, De doctrina Christiana I, XXII, 20: "Magna enim quaedam res est homo, factus ad imaginem et similitudinem Dei, non in quantum mortali corpore includitur, sed in quantum bestias rationalis animae honore praecedit."

16) For Ficino's notion of the importance of religion in human life, see his De Christiana religione, in Opera omnia, vol. 1, p. 2. Ficino's critique of previous answers to the question of the preeminence of mankind in nature, as well as his own solution, are repeated and discussed also in book XIV, chapter IX, of his Platonic Theology. See Theologia platonica de immortalitate animorum, 6 vols., eds. James Hankins with William Bowen, trans. Michael J.B. Allen with John Warden (Cambridge, MA, 2001-2006), vol. 4, 290-298. See especially 292-296. See also James Hankins' discussion in his 'Religion and the Modernity of Renaissance Humanism', in Angelo Mazzocco (ed.), Interpretations of Renaissance Humanism (Leiden, 2006), 137-153; especially 147-148. For Pico's notion see De hominis dignitate, Heptaplus, De ente et uno e scritti vari, ed. Eugenio Garin (Firenze, 1942), 104-106. It is important to notice that Pico does not use voluntas or libertas here, central terms in Salviati's discussion, but only arbitrium and arbitrarius. On the other hand, we may have an echo of a common biblical source for both Pico and Salviati, cited only by the Franciscan; see: Fridericus 169-170: "Atque hoc est id quod Eccli. 15 dicit: Ab initio fecit Deus hominem et dimisit eum in manu consilii sui, id est dimisit ei potestatem et libertatem sequi aut fugere consilium sive rationis arbitrium. Unde et subdit: Apposui tibi aquam et ignem, hoc est varias rationes contrariasque; ad quod volueris, oppone manum tuam, hoc est quam tibi placet, sponte sequaris sententiam.” The biblical verses from Ecclus. 15, 14-17 receive here an interpretation according to Salviati's own philosophical terminology, just like the citation from Aristotle in $\mathrm{n} .18$ below. We find also in Pico the expression in cuius manu te posui. On the theme of human dignity (though with a different interpretation of both Ficino and Pico) see the general discussion in Kristeller, Renaissance Thought, 169-181. It is symptomatic to Kristeller's 
the one hand, presents a fuller account based on the notions of human will and freedom as developed in scholastic philosophy up to his own day. On the other hand, his method is to reconcile different, and sometime opposed opinions, showing their concord, again, in a quite similar way to both Ficino and Pico, as well as to other humanists. ${ }^{17}$ Thus, Salviati does not explicitly reject Aristotle, Augustine, or any other authority. He just presents an interpretation of Aristotle, for instance, in which he is already using his own notions of will and freedom, which are themselves the product of the latest developments (a point to which we shall return) in scholastic thinking, but quite different from Aristotle's. ${ }^{18}$ This is of course the standard way, in scholastic philosophy,

approach that he mentions on p. 171 the facts that the earliest humanist treatment of the dignity of man by Bartolomeo Facio was encouraged by a Benedictine monk, Antonio da Barga, and that this subject is treated by him "in a strongly religious and theological context", but that he does not deal at all with the contributions of the scholastic philosophers to this theme in the fifteenth century. A more detailed discussion of this theme, with a yet different approach, in which the scholastic tradition is better appreciated, can be found in Charles Trinkaus, In Our Image and Likeness - Humanity and Divinity in Italian Humanist Thought, 2 vols. (London, 1970), vol. 1, 179-321.

17) For Salviati's method see Fridericus p. 157: "At veritati (id nosti) veritas-veluti nec bono bonum-opponitur numquam." See also the citations in Šojat's introduction, Fridericus p. 35, n. 56, from Salviati's Opus de natura caelestium spirituum quos angelos vocamus: "Mihi certo Thomas non minus carus Scoto. Uterque enim praestans, uterque doctus, uterque sacrae fidei validus propugnator. Ubi convaluero conciliare, id facere enitar"; and from his Propheticae solutiones pro Hieronymo Savonarola: "Verum est... illum modum a supra dicto doctore [Scoto] multifariam impugnari; forsan tamen posset conciliari Thomas et Scotus vel eo in loco, sed haec praetereunda in praesenti iudico." See also Šojat's remarks on p. 65. On this same issue see also Vasoli’s remarks in his Profezia e ragione, e.g., 34, 41-42. This method is very close to Pico's method in his famous Conclusiones of 1486. See Giovanni Pico della Mirandola, Conclusiones, ed. Bohdan Kieszkowski (Genève, 1973), p. 54: "Conclusiones paradoxe numero XVII secundum propriam opinionem, dicta primum Aristotelis et Platonis, deinde aliorum doctorum conciliantes, qui maxime discordare videntur." For Salviati's use of the same principle in another context, in his commentary on Lorenzo de' Medici's poem, see Vasoli, Filosofia e religione, 164-165. On this issue see also Frederick Purnell, Jr., 'The Theme of Philosophic Concord and the Sources of Ficino's Platonism', in Gian Carlo Garfagnini (ed.), Marsilio Ficino e il ritorno di Platone: studi e documenti, 2 vols. (Firenze, 1986), vol. 2, 397-415.

18) See, e.g., Fridericus p. 174: “Mentem' Philosophus totam in intellectivam animam vocat, cuius hae sunt duae potentiae: voluntas et ratio. Unde quia mens pro ratione saepissime capitur, se non ita capere ostendit X libro, inquiens: 'Quodsi felicitas operatio est profluens per virtutem, consentaneum est rationi ut sit ea operatio quae per optimam proficiscitur; hoc autem eius erit profecto quod est praestabilissimum atque optimum,-_ive igitur mens sit hoc, sive aliquid aliud quod quidem natura dominari videtur ac imperare'. At voluntas est illa quae praecipit, naturaque dominatur; indistincte itaque et absque delectu utramque potentiam 'mentis' vocabulo comprehendit." 
of presenting new ideas. If some thinker somehow manages to relate his new notion of the human will and freedom, say, to Aristotle, then this is how this new notion should be presented. But as we shall see, through the dramatic dynamic of the dialogue, Salviati managed also to preserve the sense of novelty regarding the theory he presents.

Salviati, then, emphasizes the essential relation between voluntas and libertas, as contrasted to natura and ratio which are not free. But he is not willing to neglect the importance of reason or of rational proceedings, as can be found for instance in Ficino's letter cited in n. 12 above. He rather prefers a broader definition of the rational soul, presented as an interpretation of Aristotle's notion of anima rationalis but which in fact includes his new conception of the will, and which could have helped him also in reconciling his own ideas regarding the human will and freedom with Augustine's:

But Aristotle uses [the terms] rational or intellectual power in discussing the whole part of the soul, that which is described as 'rational'. But only the rational soul is free yet not as being reason, but as being will. Hence he often uses [the expression] 'free agent' or 'intentional' in the same sense. But intention is firm volition of something. ${ }^{19}$

Here we have another kind of rationality, stemming from a wider conception of the rational soul, which is free and contains both reason and will. Now we are ready for Salviati's account of ratio, voluntas, libertas, and arbitrium.

According to the Franciscan, reason, as well as all senses and powers in the human soul which participate in reason, can be described as free only through participation (per participationem), whereas the will is the only power which is by itself (ex sese) free. ${ }^{20}$ But what does freedom mean here? It is mastery, or

19) Ibid., 165-166: "Aristoteles autem rationalem potentiam sive intellectivam pro tota illa anima quae 'rationalis' dicitur capit. Anima vero rationalis sola libera est, non tamen ratione, sed voluntate. Unde agens liberum sive a proposito pro eodem saepenumero accipit. Propositum autem est firma alicuius rei volitio."

20) Ibid., p. 168: "Ratio quoque et omnes sensus viresque, rationis participes, liberi per participationem dici possunt, at sola voluntas ex sese ut talis sit oportet." This is a standard Scotist position: "Potentia libera per participationem, quae subest libertati voluntatis, non magis determinatur secundum actum suum circa minimum obiectum quam maximum, ut patet de visu, quod non magis determinatur ad videndum solem quam aliud visibile; igitur multo fortius voluntas, quae libera est per essentiam, non magis determinabitur ad volendum unum quam aliud.” This citation from Scotus' first commentary on the Sentences (Lectura prima, d. 1 p. 2 q. 2, n. 99) is quoted and discussed in Guido Alliney, 'La contingenza della fruizione beatifica nello sviluppo del pensiero di Duns Scoto', in Via Scoti. Methodologica ad mentem Joannis Duns Scoti. Atti del Congresso Scotistico Internazionale, Roma 9-11 marzo 1993, ed. Leonardo Sileo 
the ability to control or perform its own acts. Only the will is the ruler of this kingdom in our soul; all the other powers should be regarded only as handmaids or followers of this ruler. ${ }^{21}$ Salviati moves on to present an argument showing that there is no disagreement with Thomas here, since no one, including the angelic Doctor himself, would ever ask whether reason can be compelled to act in this or that manner, but only whether the will can be thus compelled. Thus, compulsion is related by every one to reason, while acting contingently (contingenter) is the way of the will. Without this distinction, Salviati argues, how can some Doctors discuss whether some one can necessarily will the supreme good? In such discussions the assumption is always that freedom and the will are strongly related. All this proves, Salviati concludes, that if we have freedom in us, it consists in the will. Hence, if someone declares that our will is not free, this goes against reason, experience and our faith. ${ }^{22}$ It is important to notice that Salviati first constituted the relation between freedom and the will, defining each of these elements in the human soul, and distinguishing them from all the other natural and thus necessary elements such as reason and the senses. Only then does he go on to discuss another related term: arbitrium.

The discussion of arbitrium begins with a question raised by Octavianus, one of the two interlocutors in the dialogue, who, as mentioned above, tried in the first chapters ${ }^{23}$ to persuade Fridericus, the second interlocutor who represents Salviati's own views, that the intellect is the most noble power in the

(Roma, 1995), vol. 2, 633-660; see p. 636 and n. 13 there. A discussion of the rational will in Scotus can be found in Mary Beth Ingham, 'The Birth of the Rational Will: Duns Scotus and the Quaestiones super libros Metaphysicorum Aristotelis, Book IX, Quaestio 15', in Medioevo XXX (2005), 139-170.

21) Ibid.: "Cum autem libertas nil aliud sit quam ad suum actum eliciendum aut producendum (per idque ceteras potentias ad operationes suas reducendum) dominium sive potestas, voluntas certo sola huius regni nostri domina erit, reliquae potentiae pedissequae putabuntur."

22) Ibid.: "Neque (ultra dictas rationes) longe ab haeresi est dicere voluntatem non esse per se liberam. Ad quid quoque neque sanctus Thomas, neque ullus alius quaesivit umquam 'an ratio compelli potest', sed 'an voluntas', dicuntque omnes eam solam contingenter ferri ad omnia obiecta, neque dissentit in hoc ullus, praeterquam de summo bono, quod quidam dicunt ut necessario velit? Haec sunt signa quod si qua in nobis libertas est, ea sit in voluntate. Unde rationibus, experimento, fideique nostra repugnat si quis voluntatem nostram non esse liberam dicat." For the sources at the background of Salviati's argument here, such as Thomas Aquinas as well as Henry of Ghent, Giles of Rome or Peter John Olivi, see Šojat's references and citations on 168-169.

23) Ibid., 144-156. 
human soul. Consistent with his line of thought, though admitting that he must accept Fridericus' arguments, Octavianus says:

I am now forced to accept these [arguments]. But why do we sometimes say that we have free judgment, when to give judgment, just like to have an opinion or to judge, would be the act of reason? ${ }^{24}$

A good question, originating from the distinction between reason and will, and also from the common use of liberum arbitrium as free will. Octavianus is willing to accept the phrase voluntas libera, but in the light of the previous arguments and distinctions the phrase liberum arbitrium seems now misleading. Here Fridericus/Salviati takes recourse to the other kind of rationality we discussed earlier:

Human judgment [iudicium sive arbitrium] is free both while preceding the will and while following it: for, while we have this determination by the intellect 'this thing is indeed better, but that is worse', yet the will is free in pursuing what is worse, and also in not willing what is better, or certainly in taking an indifferent position. Whence Ovid represented this Medea in book six of his Metamorphoses as thus saying: 'I see and approve the better things, / [but] I follow the worse things'. Certainly a most clear and true sentence! And so free is our judgment, because, just as to know, so also to judge what is good does not make us good, but only accepting and willing it. And so free judgment is the free election or acceptance of judgment. $^{25}$

24) Ibid., p. 169: "Compellor his iam adhaerere. Sed cur dicimus interdum arbitrium nos habere liberum, cum arbitrari, sicut et opinari aut iudicare, sit rationis actus?"

25) Ibid.: "Humanum iudicium sive arbitrium liberum est ut praecedit voluntatem et ut sequitur eandem: data enim ab intellectu sententia 'hoc quidem esse melius, id vero deterius', voluntas libera est ad prosequendum deterius, atque ad non volendum melius, aut certo ad standum indifferenter. Unde Medeam illam VI [this reference is corrected by Šojat: it should be to book VII, 20-21] libro Metamorphoseos Ovidius introducit sic dicentem: 'Video meliora proboque, / deteriora sequor'. Praeclara certo veraque sententia! Liberum itaque est nostrum arbitrium, quia veluti scire ita et iudicare bonum non facit nos esse bonos, sed id acceptare et velle [Šojat provides here a reference to Scotus]. Liberum itaque arbitrium est libera iudicii electio sive acceptatio." For the fortuna of this example of Medea as a case of akrasia in the later tradition, starting with Lévefre d'Étaples, see Risto Saarinen, 'Weakness of Will in Renaissance and Reformation', in Tobias Hoffmann, Jörn Müller, and Matthias Perkams (eds.), The Problem of Weakness of Will in Medieval Philosophy (Leuven, 2006), 329-351; especially 334-347, 350-351. But as we can see here, we find the example of Medea already before Lévefre d'Étaples, in Salviati's scholastic discussion of the will. Thus, against Saarinen's general conclusions on p. 337, for instance, we can say that the scholastic thinkers were less restrictive in their illustrations, and that neither Lévefre d'Étaples nor Josse Clichtove "have been the first commentators to have employed this example". Fifteenth-century scholasticism and its dialectical relations with, and mutual influence on, 
Only when free election or acceptance are involved can we speak of free judgment. And this, as we have seen, is peculiar to man. Salviati emphasizes the fact that he discusses here the human judgment. We are beyond the dichotomy rational/irrational through the new notions of freedom and will in the human soul, which presents a more complex picture of human psychology. But this complexity gives us a better account of most human actions in reality, and it bears also some important ethical and theological implications. The possibility of deliberately choosing to commit an evil deed or a sin given by our free and post-lapsarian will is exactly what gives us as human beings the possibility of becoming good and as Christians of being saved. Another implication is that in fact there are two kinds of judgments: one of the reason (arbitrium rationis) and one of the will (arbitrium voluntatis). This observation is of course not new. But human judgment as we have seen in Salviati's arguments derives only from the will and thus is free. Salviati is using the biblical verses of Sirach (Ecclesiasticus) 15, 14-17, to show that man can escape the judgment of reason and thus act freely. In fact, man received this ability from God Himself. ${ }^{26}$ When we consider, for instance, Thomas' view of arbitrium rationis we see a wholly different psychology, in which, so it seems, the Aristotelian notions of homo rationalis and prudentia are still strongly reflected. ${ }^{27}$ Thomas' declaration that homo est dominus suorum actuum per arbitrium rationis is totally opposed to Salviati's view. ${ }^{28}$ But during the two hundred years between Thomas' death in 1274 and the activity of Salviati, a whole new psychology had emerged in scholastic philosophy, and this new psychology is clearly reflected in Salviati's discussion of the human will written during the 1470 s. $^{29}$

the humanist movement is still a task for further studies based on unstudied works such as Salviati's.

26) I have already quoted this passage from Fridericus, $169-170$ in n. 16 above.

27) See, e.g., Thomas Aquinas, Summa theologiae, 2a2ae, q. 47, a. 12: "Sed quia quilibet homo, inquantum est rationis, participat aliquid de regimine secundum arbitrium rationis, intantum convenit ei prudentiam habere."

28) Ibid., q. 158, a. 2: "Ad tertium dicendum quod homo est dominus suorum actuum per arbitrium rationis; et ideo motus qui praeveniunt judicium rationis non sunt in potestate hominis in generali, ut scilicet nullus eorum insurgat; quamvis ratio possit quemlibet singulariter impedire, si insurgat."

29) For detailed discussions of this new psychology in scholastic philosophy during the later part of the thirteenth century and the first decades of the fourteenth century, see the studies of Guido Alliney, 'La contingenza della fruizione beatifica'; 'Fra Scoto e Ockham: Giovanni di Reading e il dibattito sulla libertà a Oxford (1310-1320)', in Documenti e studi sulla tradizione filosofica medievale 7 (1996), 243-368; 'La ricezione della teoria scotiana della volontà nell'ambiente teologico parigino (1307-1316)', in Documenti e studi sulla tradizione filosofica medievale 14 (2005), 
Two points in this new psychology are essential for our present discussion: first, the human will is not bound by any necessity to achieve the supreme good, or even to aim it, and this is an expression of its freedom (as opposed to natural and thus necessary causes), through which man can also turn himself away from the supreme good; and second, man's primary condition, through which he can turn himself towards the supreme good, is determined only by his free will.

This second point implied some restriction on the late Augustine's severe notion of grace in the post-lapsarian state. Both points reflect different notions of human rationality than what we had in Thomas. Some one like Henry of Ghent, though still maintaining necessity in the act of the will towards the final end, is extremely important in developing these new emphases. ${ }^{30}$ Thinkers like Peter John Olivi and Gonsalvus of Spain in Paris seem to have exercised some influence upon the philosophical formation of the best-known thinker related to this later development in scholasticism: John Duns Scotus. ${ }^{31}$ While the first generation of Scotists in the early fourteenth century tried to reconcile the more extreme position of Scotus himself (regarding the possibility of using free will and turning away from God also in patria) with the more traditional doctrinal view (thus maintaining some kind of necessity in patria in order not to offend God's perfection and the perfect happiness of the beatific vision), it will be interesting to see what Salviati's view on this issue is. As we have seen, he seems to accept Scotus' position in via. ${ }^{32}$ Since we do not have yet enough detailed studies of fifteenth-century scholasticism and Scotism, we

339-404; 'The Treatise on the Human Will in the Collationes oxonienses Attributed to John Duns Scotus', in Medioevo 30 (2005), 209-269. See also Stone, 'Moral Psychology After 1277'.

30) Alliney, 'La contingenza della fruizione beatifica', p. 634. See also C. G. Normore, 'Picking and Choosing: Anselm and Ockham on Choice', in Vivarium XXXVI (1998), 23-39; see especially $31-33$.

31) Alliney, 'Fra Scoto e Ockham', 251-253. Scotus' theory of the will is much more complicated than what is provided in the present presentation, but it is beyond the scope of this discussion, which is focused on Salviati and the fifteenth-century context. Scotus distinguishes between liberty and nature and between contingent and necessary activity: each power can act either according to nature or according to liberty. All powers except the will are natural and thus necessary and not free. The will is a free power which acts contingently. It is impossible, according to Scotus, that the same power will act in a different way while being in via or in patria. Thus, the will acts freely and contigently also in patria towards the supreme good and beatitude, and can 'not will' it. But this 'not willing' in patria does not imply any evil or any offence towards the perfection of the supreme good. See: Alliney, 'La contingenza della fruizione beatifica', p. 639.

32) On these tensions among Scotist thinkers in the early fourteenth century see Alliney, 'La ricezione della teoria scotiana', 371-372. 
must restrict our general observations. ${ }^{33}$ Let us now turn back to Salviati's discussion, bearing in mind this general orientation.

As we have seen in the case of arbitrium, where the phrase arbitrium liberum seemed at first sight misleading, and a new definition was required in the light of the other distinctions, Salviati is using the same method also in his discussion of appetitus in chapter 13. While presenting Thomas' view of appetitus and voluntas he argues that there is a confussion in this discussion between appetitus naturalis and voluntas. It is right to relate the natural appetite to the intellect, and to describe this activity as necessary, but it is wrong to identify every appetite with the will. Salviati seems to be concerned about this obscurity and about the confusion in the common way of using these terms. ${ }^{34}$ Thus, for instance, we find in the 1474 dispute between Ficino and Bandello a rational appetite which is related to the intellect, and a sensual appetite which is related to the will. Since Ficino is not relating his notion of the will to freedom, and certainly not contrasting it with nature or with natural and necessary causes (such as the senses, for instance) he is left with an diminished notion of the will, which is ruled by an irrational and sensual appetite, and thus he is justly criticized by his Dominican rival, who was only interested in restoring the preeminence of the intellect in the human soul. ${ }^{35}$ This might be

33) Yet one should mention here for instance, Maarten J.F.M. Hoenen's 'Scotus and Scotist School. The Tradition of Scotist Thought in the Medieval and Early Modern Period', in E.P. Bos (ed.), John Duns Scotus. Renewal of Philosophy (Amsterdam, 1988), 197-210; with regard to fifteenth-century debates held in Cologne between the Albertists and Thomists, mainly on logic, see Hoenen's 'Late Medieval Schools of Thought in the Mirror of University Textbooks. The Promptuarium Argumentorum (Cologne, 1492)', in Maarten J.F.M. Hoenen, J.H. Josef Schneider, Georg Wieland (eds.), Philosophy and Learning. Universities in the Middle Ages (Leiden, 1995), 329-369; with regard to one central figure in fifteenth-century scholasticism, see John Monfasani, Fernando of Cordova: A Biographical and Intellectual Profile (Philadelphia, 1992). With regard to a more minor figure see Monfasani’s 'Giovanni Gatti [i.e., Gatto] of Messina: A Profile and an Unedited Text', now in Greeks and Latins in Renaissance Italy. Studies on Humanism and Philosophy in the 15th Century (Aldershot 2004), article VII.

34) Salviati, Fridericus p. 175: "Hoc appetitu [appetitu naturali], omnem perfectionem intellectui possibilem, similiter et voluntati, expetimus; eo ipso anima tamquam suo perfectibili semper uniri corpori cupit; isto appetitu—Paulus dicebat—nolumus expoliari, sed supervestiri; hoc appetitu necessario ferimur, ducimur, agimur; hic est ille de quo sanctus Thomas ait: Voluntas ut natura necessario fertur in ultimum finem, sive in summum bonum. Vocat enim communi modo omnem appetitum 'voluntatem': sunt enim in vulgo ambigua haec nomina, involuta atque confusa." Šojat gives, in his footnotes on 175-176 the relevant references and citations from II Cor 5, 4, as well as from Thomas' Summa theologiae and De malo, against Scotus' discussion in the Ordinatio.

35) Vincenzo Bandello da Castelnuovo, Opusculum Fratris Vincentii de Castronovo Ordinis Praedicatorum ad magnificum ac generosum virum Laurentium Medicem quod beatitudo hominis in actu 
an example of what would have been regarded by Salviati as a confused contemporary discussion of the appetite, the intellect, and the will.

Against this confusion Salviati immediately distinguishes between his notion of the will which is a free power and opposed to nature, and that kind of natural appetite. ${ }^{36}$ As we have seen already, Salviati has no difficulty in putting into the mouth of his sources his own notion of the will. Thus, Paul himself, according to our Franciscan friar, talked about the free will and not about the natural appetite when he said: I long to be dissolved and to be with Christ. ${ }^{37}$ The most important element here is election (electio) which receives both theological and ethical dimensions through the examples of the martyrs and the brave moral men (virifortes). The will is defined here as a power (vis) in the soul created by God for us, through which we become free and masters of our own actions. All other things lack this unique power, and because of this they are not free. ${ }^{38}$ We should not use appetere for velle, since it describes that power through which we are necessarily being led, and is in itself an innate or natural inclination, nor should we use appetere for any operation of the will. ${ }^{39}$ Salviati

intellectus et non voluntatis essentialiter consistit incipit, in Kristeller, Le thomisme et la pensée italienne de la renaissance (Montréal, 1967), 187-278; see p. 249: "Non est autem existimandum simpliciter aliquid tale secundum ordinem appetitus sensitivi sed magis secundum ordinem appetitus intellectivi"; p. 264: "Nam ut is asserit, si deus intellectum a voluntate seiungeret, esset intellectus forma quaedam rationalis, voluntas vero esset appetitus cognitione carens. Quis enim dubitat formam rationalem omnem appetitum cognitione carentem dignitate praecedere?" These critical remarks should be referred to Ficino, Lettere I, p. 208: "Appetitus nullus rem imaginariam querit, sed substantialem, alioquin sufficeret appetenti absentis boni memoria atque imaginatio; visio autem Dei in nobis imaginaria res est et, ut supra dixi, finita. Quocirca voluntatis actus, qui est in Deum infinitum conversio substantialisque diffusio, rationem infinitatis magis habet quam actus intelligendi, qui est Dei notio quedam pro mentis capacitate."

36) Salviati, Fridericus p. 176: "Ast nostra haec voluntas, de qua disputamus, nulla in condicione cum appetitu dicto convenit: neque enim est naturalis potentia, neque inclinatio quaedam (nisi forsan, mediante actu quem libere elicit, imperando et iubendo inclinet); estque quo desideramus frequenter opposita illi appetitui."

37) Ibid.: "Voluntate enim libera, non appetitu naturali, dicebat Paulus: Cupio dissolvi et esse cum Christo." Šojat gives the source in his notes: Ph 1, 23.

38) Ibid.: "Et ut brevi congeram plurima, hac fit omnis electio: hac enim martyres illi subdebant se doloribus et neci, hac viri fortes adsciscunt sibi potius mortem quam turpem gerere vitam. Unde voluntas nil aliud est quam vis quaedam animae, a Deo in nobis creatae, qua liberi operationumque nostrarum domini sumus. At ceterae res, veluti nec libertatem, sic ne hanc quidem, qua quisque liber est, habent potentiam; neque itaque voluntatem."

39) Ibid.: "Unde quae volumus, non proprie appetere dici debemus, cum appetere vim quandamqua ducimur-necessario designet, sitque ea ipsa inclinatio innata, neque ulla eius operatio." A completely different approach, in which the appetite is related to freedom and will, in a 
presents a typical scholastic concern for accuracy in the use of terms: while desiderare and cupere can be related to the will, appetere should only be related to that inclination through which someone is seeking that thing which has a perfect nature, and this is of course the will. ${ }^{40} \mathrm{His}$ critique here of most learned men (doctissimi viri) should remind us of the intellectual context in which Salviati was active: fifteenth-century Italy, where humanists and scholastics shared a common interest in philosophical and theological questions. Such a common interest may produce also some inaccuracies in the use of terms. ${ }^{41}$

Neoplatonic framework in which an eternal will is described as some kind of cosmic law, can be found in Ficino's Theologia platonica vol. 1, p. 296: "Quonam pacto caelestes animae sphaeras suas movent? Profecto quemadmodum placet Platonicis, sicut corpus tuum anima tua per appetitum. Qui appetitus illic quoque a cogitatione excitatur, cogitatio ibidem a fatali illius animae lege. Ideo Plato in libro De regno inquit: 'Caelum movet fatum et innata cupiditas'. Quod accepisse videtur a Zoroastre, a quo omnis manavit theologorum veterum sapientia. Ille enim ubi de

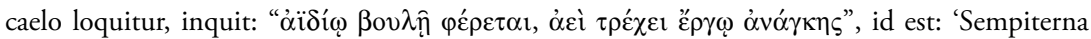
voluntate fertur, semper necessitatis opera currit'. Quod perspicue intellegemus, si ita rerum ordinem considerabimus."

40) Ibid.: "Sed doctissimi viri, vulgo consentientes, velle beluas et reliquas res insensibiles saepe dicunt,-_similiter et hominem voluntate appetere. Sed homo desiderare vel forsan cupere quoque voluntate dici potest; appetere solum illa inclinatione qua petit id quod sibi est natura perfectum, dicendus est (veluti grave centrum, leve circumferentiam)."

41) We may think of Coluccio Salutati's discussion of the superiority of the will to the intellect in his famous and influential composition De nobilitate legum et medicinae, ed. Peter Michael Schenkel (Munich, 1990), 182-196, as an example of a confusion between voluntas and appetitus; see p. 182: "Voluntatis inquam, que non sit naturalis vel sensitivus appetitus, quorum ille movetur sine cognitione, iste vero cuiusdam particularis boni noticia, sed voluntatis, cuius liberum sit arbitrium, quod est actus voluntatis et rationis. Nam cum ille primum [scil. naturalis appetitus] sit in plantis, secundus [scil. sensitivus appetitus] in sensibilibus, tamen hec tertia [scil. voluntas] in creaturis ratione utentibus invenitur. Siquidem ipsa voluntas est omnium potentiarum anime, quas eminere vegetative cognoscimus, imperatrix." Hec tertia may cause a confusion, implying that the will is a special third kind of appetite, and not a unique power which is essentially different from all the rest. But it is obvious that Salutati is well aware of this essential difference, and this suggests an interesting critical dialogue and dialectical relation between the humanist and the scholastic. On the relation between Salutati and some of the humanists with Scotist masters see the general remark of Vasoli in his Profezia e ragione, p. 37. On Salutati and the will see also Trinkaus, In Our Image and Likeness, vol. 1, 51-102. A much more confused discussion can be found in Lorenzo Valla's De libero arbitrio, in Opera omnia, 2 vols. (Torino, 1962), vol. 1, p. 1003: "Prius tamen de hoc posteriore breviter satisfaciam, ubi ais, si deus futura prospicit, quia futura sunt, necessitate illum laborare, cui necesse est eventura prospicere. Hoc vero non est tribuendum necessitati, sed naturae, sed voluntati, sed potentiae" For a critical discussion of Lorenzo Valla's treatments of theological issues see John Monfasani, 'The Theology of Lorenzo Valla', in Jill Kraye and M.W.F. Stone (eds.), Humanism and Early Modern Philosophy 
Salviati's conclusion is thus that appetitus and voluntas belong to completely different species, and that the appetite should be related to the intellect but strictly distinguished from the free agent. ${ }^{42}$

In the beginning of chapter 14 we find a rhetorical description of the importance of the will:

Who indeed does not know that God Himself subjected all other powers to the will? Certainly all intentions, every persuasion, every command is issued by the will. Indeed, who is the one who has ever told his eye 'do not see', or to his hand 'do not grasp', or his intellect 'think of this, but not of that? ?43

After again reading his notion of the will into some biblical verses, ${ }^{44}$ Salviati argues that the will is the only power in the soul which is related to both sinners and pious men; this is the central quality for theology and ethics and it controls all our actions and deeds. ${ }^{45}$ While rejecting the opinion of the fourteenth-century Doctor Franciscus Baconis (Doctor Sublimis) which was brought into the discussion by Octavianus to show that the will is directed,

(London, 2000), 1-23. Another critique of the humanist's contribution, also including an evaluation of Pomponazzi in regard to divine foreknowledge, can be found in Chris Schabel, 'Divine Foreknowledge and Human Freedom: Auriol, Pomponazzi, and Luther on "Scholastic Subtleties"', in Russell L. Friedman and Lauge O. Nielsen (eds.), The Medieval Heritage in Early Modern Metaphysics and Moral Theory, 1400-1700 (Dordrecht, 2003), 165-189.

42) Salviati, Fridericus p. 177: "Appetitus itaque omnis sub eodem genere cum potentiis apprehensivis cadit: sunt enim natura agentia. Voluntas una ex altera parte manet, agensque liberum vocitatur, habetque quandam pertenuem cum appetitu concordiam. Sed intellectus etiam cum appetitu maiorem videtur habere convenientiam, ex quo una cum ipso libero agente condividitur."

43) Ibid.: "Quis vero ignorat Deum ipsum omnes vires alias commisisse voluntati? Omnia enim consilia, omnis persuasio, omne praeceptum voluntati fit. Quis enim est qui umquam dixerit oculo 'non inspicias', aut manui 'non rapias', aut intellectui 'cogites hoc, illud vero minime'?"

44) Ibid., 177-178: "Unde et Deus ita praecipit: Diliges Dominum Deum tuum ex toto core, ex tota mente, ex omnibus viribus tuis. Voluntati dicitur: Honora patrem tuum et matrem. Sibi dicitur: Non occides, non mechaberis." The biblical references are given by Šojat in the notes in p. 178.

45) Ibid., p. 178: "Nullus enim nolens aut peccat aut meretur, solaque voluntas peccare et mereri potest, ac nulla ceterarum virium absque voluntate. Unde nec laude aut probro in his quae praeter nostram fiunt voluntatem afficimur, nisi interdum forsan per accidens, ut cum nolentes quidpiam efficimus, cuius causam voluimus, aut nolle poteramus (veluti is qui ebrius quempiam percutit, nolens quidem id agit, sed voluit—aut certo non potuit nolle—-tantum vini sumere). Voluntas est igitur omnium motionum nostrarum regina." It is interesting to find the same example also in Salutati's De nobilitate p. 194: "Unde non bibimus quia vinum habemus, sed bibere possumus cum habemus; habere quidem vinum et bibendi spatium atque locum occasio sunt, sed bibendi voluntas est causa." 
regulated, and arranged by the intellect, and that it is not subjected only to another will, ${ }^{46}$ Fridericus introduces into the discussion the divine will, thus showing another common sophism (sophisma) between intellectus or ratio, which mistakenly seem to control the will, and divina voluntas, which the human will must obey. ${ }^{47}$ Salviati is willing to give the intellect a much more modest role in comparison with the will: a spy or a messenger of the will, which is compared to a commander of an army. ${ }^{48}$ This gives Salviati an opportunity to introduce his interpretation of Juvenal's famous verse (Satire VI, 223: Hoc volo, sic iubeo, sitque pro ratione voluntas), in which he sees a critique of human arrogance and of those who are not subjecting their own will to the will of their masters or to the will of the gods, thus turning their own will into the supreme reason and rule. ${ }^{49}$ But according to the theologians, there is no higher reason than the will of God. ${ }^{50}$ We now have to determine the relation between the human and the divine will.

46) Ibid., 178-179: "Attuleram (diu est) voluntatem subiici rationi atque obedire, quia—Doctore etiam Sublimi teste-intellectu dirigitur voluntas, eique conformatur ipsa, unde et regulat eam atque ordinat. Neque, ut dixi, schola Subtilis huic opinioni adversatur. Dixisti tamen paulo ante, voluntatem nullo pacto subiici posse cuipiam, nisi forsan voluntati"; on p. 178 Fridericus argued that "Mens igitur et omnes vires commissae sunt voluntatis nutibus; eius vero nutus Dei maiorumque nutibus obtemperare debent. Inventi itaque voluntatem subiici voluntati; at voluntatem non voluntati subdi aut subesse, est impossibile." On Franciscus Baconis see Šojat's note on 178179. A much more detailed study is required on Baconis and his influence on fifteenth-century disussions of the will. Thus, Šojat could not find this opinion in Baconis' commentary on the Sentences. We should not ignore, however, the obvious rhetorical word-play here between Doctor Sublimis and schola Subtilis, a part of Salviati's humanistic style.

47) Ibid., p. 179: "Bona utique ratio talis dici solet: et huic rationi voluntas humana parere debet. Haec vero ratio non est intellectus ipse, sed divina voluntas. Intellectus itaque agnoscit quod humana voluntas subesse debet divinae, idque scire ad ipsum attinet. Est itaque maximum id sophisma 'intellectus scit voluntatem hanc subiici debere atque conformari primae voluntati, igitur voluntas haec subiicitur intellectui atque conformatur', veluti si dicerem 'scio te subiici regi, igitur mihi subdere'."

48) Ibid., p. 180: "Est itaque non princeps huius regni intellectus, sed speculator quidam, qui imperatori exercitus quid amici, quidve hostes moliantur insinuat,-atque nuntius quidam voluntatis dici potest."

49) Ibid.: "Eam ob rem et Satyrus ille obiurgat eos ipsos homines qui suam voluntatem maiorum deorumque voluntati subiicere non curabant, ita inquiens: 'Hoc volo, sic iubeo, sitque pro ratione voluntas', id est habent suam voluntatem pro prima ratione, primaque regula,-quod profanum esse liquet." We have already seen (in n. 25 above and context) Salviati's use of Ovid.

50) Ibid.: "Unde et theologi, post multotiens replicatam quaestionem cur aliquid sit, hanc ultimam ponunt rationem: 'quia Deo placuit, aut quia sic ipse voluit'; hanc rationem alia quavis ratione carere aiunt." 
Essential to this relation between human and divine will is, of course, divine grace. Salviati, following Scotus against Thomas, argues that the grace of God should be related only to the powers of the soul and not to its essence, and among these powers only to the will. ${ }^{51}$ He goes on to discuss the three theological virtues which he regards as belonging to the will. ${ }^{52}$ In his discussion of faith we have again a good example of the new psychology and anthropology, according to which powers and acts, all ruled by the will, replace the dominance of essence and the virtues in the more traditional Aristotelian and Thomistic psychology. The human soul contains powers which under the command of the will, and with some help of the virtues, are roused to action. The will creates the impulse (conatus) without which nothing can take place. The most basic act of believing is completely dependent on this impulse. The assumption here is that since matters of faith are supernatural, man cannot use a natural power like reason (and thus, since anyhow man's limited mind cannot understand the objects of faith, understanding is replaced by movement initiated by a certain inclination and impulse), but only a non-natural power like the will can make man move towards faith. This dynamic psychology is very far from passive fideism, which is often contrasted to intellectual tendencies in theological thinking. ${ }^{53}$ Salviati does not miss another opportunity for biblical interpretation, this time of a more "philological" nature. ${ }^{54}$

\footnotetext{
51) Ibid., p. 181: "At ipsa [Gratia Dei], si in aliqua animae potentia ponitur, in voluntate profecto ut ponatur arbitrantur omnes. Neque hic discutiendum est an essentiam animae sive potentiam perficiat: ostensum enim a plerisque exstat, eam non posse nisi mediante potentia uniri animae. Et vero potentia voluntas." Šojat gives references to both Scotus and Thomas in his notes on p. 181. 52) Ibid., p. 182: "Tres, denique, theologi praecipuas ponunt virtutes: fidem, spem, caritatem, suntque omnes fere voluntatis."

53) Ibid.: "At fides absque voluntate ad actum suum non progreditur: cum enim, ut ait Apostolus, sit substantia sperandarum rerum, argumentum non apparentium [Heb 11, 1], speranda vero credere et argumentis non apparentibus moveri ipsi rationi ex sese impossibile est (sunt enim intellectui eiusmodi neutra; sed id quod neutrum apparet, id est neque verum neque falsum, mentem quoque neutram reddit, neque ad ullam flectit partem: enimvero, propter spem quae promittitur, imperat intellectui voluntas ut ei parti sese coniungat quae a tam magna pollicente dicitur esse vera), constat igitur nos nil credere posse nisi applicemur, immo quasi vi ducamur ab ipsa—cui praemia promittuntur-voluntate. Credimus enim pleraque quorum opposita magis mentem movent: quod sine voluntatis magno conatu fieri non potest." Salviati's famous contemporaries who are usually regarded as "fideists" are Girolamo Savonarola and Giovanfrancesco Pico della Mirandola.

54) Ibid.: "Unde et Salvator exprobravit incredulitatem Apostolorum et duritiam cordis, hoc est voluntatis. Et euntibus in Emmaus, $O$ stulti-ait—et tardi corde ad credendum. Sed in sacra Scriptura 'cordis' nomine voluntas intelligitur. Fidei igitur actus a voluntatis iussu magna in parte dependet." Šjojat's referece to Mc 16, 14, and Lc 24, 25, is in the notes on p. 182.
} 
In the discussion of caritas Octavianus is the one who brings in Scotus' discussion of lumen gloriae and caritas. ${ }^{55}$ What seems more interesting is the conclusion:

Yet in Christ the wayfarer [viatore] both vision and love [caritas] were not without injury. ${ }^{56}$

What we do not have here is a discussion of the will in Christ, and whether it too was injured while being in via. This is why this discussion in chapter 16 ends with Octavianus' question regarding the way in which the will operates: can it operate upon objects which were apprehended by the senses, or only upon objects which were previously known by reason? ${ }^{57}$ From the point of view of all the previous distinctions, this is an eristic question, since it takes into consideration either a sensual way of operating upon singulars, or an intellectual way of operating upon universals. But in fact, as Fridericus points out in chapter 17, entitled: quod voluntas operari potest circa quodcumque singulare quomodocumque dicatur cognitum, a man who knows this specific picture can express his love towards it, from which pleasure follows; whereas a man cannot love things unknown to him, yet he can love in some way things known to him. ${ }^{58}$ Since as we have seen, Salviati presents a psychology of powers, nothing can prevent a man from willing what he sees. Since all these cognitive powers are arranged towards this thing (potentiae cognitivae ad id ordinatae), they operate upon objects which are present in the will, and thus they are all subjected to the will. ${ }^{9}$

In the next chapter, entitled: rationes quibus contemplationem effert philosophus, omnes ad voluntatem referri hic apertius ostenditur, Salviati deals with another question of Octavianus: why does Aristotle seem to praise only the intellect, and he hardly ever mentions the superiority of the will. ${ }^{60}$ This should be

\footnotetext{
55) Ibid., p. 184. References to Scotus are in Šojat's notes.

56) Ibid.: "In Christo tamen viatore et visio et caritas non sine calamitate erant."

57) Ibid., p. 188: "Sed id unum, quod multo tempore dubitavi, ut discutiamus cupio: possit necne voluntas ferri in aliquid visu apprehensum aut quopiam alio sensu, an solum in ea fertur quae ratio quopiam modo praenovit?”

58) Ibid., p. 191: "Cur igitur homo, qui hanc picturam agnoscit, non poterit erga eam elicere amorem, ex quo sequitur voluptas? Unde quamvis homo non possit amare incognita, potest tamen diligere quoquo modo cognita."

59) Ibid.: "Omnes enim sunt hominis potentiae. Quid itaque facit homini ut non possit, id quod videt, velle? Omnes itaque potentiae cognitivae ad id ordinatae sunt, ut obiecta faciant voluntati praesentia,- -et ita suae servitutis iugo cunctae sunt submissae."

60) Ibid., p. 192: "cur Aristoteles, intellectum ipsum ad sidera usque semper efferendo, de voluntatis
} 
regarded on the dramatic level of the philosophical dialogue as a critical questioning of all the previous discussions and praises of the will we have seen; but it also presents Salviati's own awareness of this problematic fact which is a complicated issue also for modern scholars. ${ }^{61}$ This may reflect Salviati's awareness of the novelty of the theory of the will he presents here; but at the same time, as a scholastic thinker, he cannot just neglect such an authority like Aristotle. As implied in the title of this chapter, the solution will be presenting arguments which show that what Aristotle ascribes to contemplation (and to the intellect) should in fact be ascribed, as more clearly (apertius) shown by all (philosophers or interpreters of Aristotle), to the will. This still means that a detailed interpretative effort is required in order to modify some basic Aristotelian notions and bring in the new notion of the will. Such a critical question and awareness of novelty may also imply the influence of humanistic methods and ways of thought in which detailed textual comparisons and a clearer critical notion of the past with regard to the present can be found. We are moving away from Aristotle both in time and in philosophical notions, and the process of reconciliation can present also a historical and philosophical awareness of this growing gap. Salviati continues to break traditional Aristotelian distinctions: we have just seen his critique of the distinction between sensual operations upon singulars and intellectual operations upon universals; here we have a critique of the distinction between theoretical and practical knowledge. ${ }^{62}$

\footnotetext{
praestantia numquam vel minimam fecit mentionem? Mirum est enim ut de tanta sublimitate eius nil umquam dixerit."

61) The problem of the will in Aristotle and in ancient philosophy in general has been the subject of many discussions in recent years. See e.g., the detailed discussion, with further references, in Albrecht Dihle, The Theory of Will in Classical Antiquity (Los Angeles, 1982). See also the discussion of Richard Sorabji in his 'The Concept of the Will From Plato to Maximus the Confessor', in Thomas Pink and M.W.F. Stone (eds.), The Will and Human Action From Antiquity to the Present Day (London, 2004), 6-28.

62) This critique is most clearly expressed in Octavianus' first critical question at the very beginning of the chapter; see Salviati, Fridericus p. 192: "Contemplatio illa in qua Philosophus summum bonum collocasse videtur, quae Christi quoque Salvatoris testimonio est optima pars, in ipso quidem intellectu est. Virtutes vero morales, quae ad voluntatem spectant, non sunt ipsa contemplatione-ut placet omnibus_-praestantiores." Šojat refers in his notes to the relevant sources here: Aristotle's Ethics and Thomas' commentary on the Ethics, as well as Lc 10, 43. Salviati's solution is on p. 195: “'Virtutes morales magis indigent his quae ad vitam sunt necessaria quam contemplativus'; ac si dicat: eo quo minor cura voluntati datur, si bonum sit aeque ut aliud, carius sibi gratiusque fit. Sic vero sese habent virtutes morales ad ipsum contemplationem. Quare praestabit contemplatio causa voluntatis.”
} 
Since Aristotle regarded the intellect as the best part in us, it should be regarded as extremely loveable (summe amabilis). This immediately brings the will into the picture since, Salviati argues, the good, the better, and the best are all objects of the will (and the operation of the will is love); and so, nothing is loveable for us which is not under the power of the will, since we can love something only through the will. The power of the will is thus the reason for anything which is best in us, and without it there will be no good or best part in us. ${ }^{63}$ Salviati presents this kind of arguments, in which he identifies terms such as mens, intellectus, contemplatio, sapientia, felicitas with summum bonum, through which he can bring in amor, and of course voluntas, in the rest of this chapter. $^{64}$

In chapter 19, entitled: quod vera beatitudo in voluntatis operatione consistat et sine illa nullus beatus esse possit, Salviati presents his clear answer to the same question discussed also by Ficino, Lorenzo de' Medici, and Vincenzo Bandello. He uses the same kind of arguments we have seen in the previous chapter. ${ }^{65}$ By the end of the chapter Salviati presents his critique of Thomas' view, according to which Thomas prefers a non-contingent (and thus a stable) act like vision to the contingent act of the will in regard to the supreme good. ${ }^{66}$ Salviati uses again the same rhetorical argument:

... should a man be described as blessed who sees, and yet does not love? But this is impossible: since someone is blessed from the point of view [sub ratione] of the supreme good; but

63) Salviati, Fridericus 193-194: "'Mens quippe ait [Aristoteles] est optima eorum quae nobis insunt'. Bonum namque, melius, optimumque, veluti obiecta, aut certo eorum respectus, ad voluntatem, ut diximus, referuntur. Optima igitur est mens, hoc est maxime amabilis, praeclarissima est mens, id est voluntati gratissima. Summe enim praeclarum optimum est; quod vero optimum, id amore dignissimum: universis nempe potentiis intellectus magis expetitur. Unde iam quod ipse Philosophus non distinguit voluntatem ab homine, sicut ceteras potentias remotas? Optimus namque nobis est intellectus, hoc est summe amabilis; nil vero nobis amabile quod non et voluntati (nos enim voluntate diligimus); quidquid igitur nobis optimum, id voluntatis ratione dicitur (nulla enim voluntate exsistente in nobis omnino, nulla utique res aut bona nobis aut optima foret)."

64) Ibid., 194-198.

65) Ibid., p. 200: "Beatitudo, felicitas, ultimus finis et summum bonum (ut paulo ante diximus) — idem sunt; at summum ipsum bonum voluntatis est sub ea ratione: neque enim est obiectum intellectus, ut bonum est, quidpiam; cuius itaque obiectum est summum bonum, eius est et beatitudo, eius et felicitas atque finis ultimus."

66) Ibid., p. 202: "Ait [Thomas] enim: voluntas quoad eliciendum actum, contingenter se habet erga quodcumque obiectum; quae autem contingenter se habent, possunt non fieri; posita igitur visione, non eliciet voluntas necessario actum circa summum bonum.” 
the supreme good is related to the will, which if it is not in us, indeed we shall have no happiness. Many most sagacious people think that in the last day of judgment also those who are damned will intuitively see God but yet will not love Him. Thus, happiness consists in love. ${ }^{67}$

The emphasis here is on the superiority of love to vision and understanding. We have already seen that love is an act of the will. As we shall see in the next chapter of Salviati's text, it represents a disposition without which we cannot use contemplation and understanding. This chapter, too, ends with a critical question by Octavianus: if love is so essential to happiness, how come that Aristotle discussed happiness by using other terms (and not love)?68 This is another reminder of the fact that we are dealing here with a new theory of which Aristotle knew nothing through the dramatic persona of Octavianus. But Aristotle is not the object of criticism. Fridericus admits, at the beginning of chapter 20, entitled: quomodo in contemplatione dicatur consistere beatitudo quidve activa vita sit atque contemplativa, that Thomas was wrong on just this point. ${ }^{69}$ It is essential for Salviati to show that the will should not be identified with practical life only. Thus, he is not willing to accept a sharp distinction between practical and contemplative life; on the other hand, his appreciation of active life should be regarded as a result of both the humanist movement and the later developments in scholastic tradition.

Salviati begins by emphasizing again the psychology of powers: contemplation is not in itself a power, but rather it needs a power in order to contemplate. This power is like a precondition or a disposition which should be present beforehand in order to make intellectual activities possible. ${ }^{70}$ Likewise, Salviati argues, seeing is an operation adequate for observing movable objects and quantitative qualities, while God, being a free object, can be present without

67) Ibid., 202-203: "dicetur beatus si qui videt, et tamen non amat? At id fieri nequit: beatus enim quisque sub ratione summi boni est; summum vero bonum ad voluntatem refertur, quae si nulla est in nobis, nulla profecto et beatitudo erit. Tenent plerique acutissimi viri ut ultima illa die iudicii damnandi quoque Deum intuitive videbunt, neque tamen amabunt. In amore igitur consistit beatitudo." These acutissimi viri are of course mainly Scotus, and Šojat gives in his notes the relevant references.

68) Ibid., p. 203: "Quid ad ipsum Aristotelem aliosque eiusmodi dicendum?"

69) Ibid., p. 204: "Errant igitur qui dicunt obiectum beatitudinis contemplatione fieri praesens." Šjat gives in the notes the relevant passages from Thomas.

70) Ibid., 203-204: "Cum vero nil, nisi praesens sit potentiae ipsi qua sapimus, contemplari possimus, contemplatione non fit 'id quod intelligitur' praesens: praecedit namque rei praesentia contemplationem eique praeponitur; sed iam id quod est praesens, non fit per quodpiam posterius praesens." 
any movement, and thus cannot be seen. ${ }^{71}$ The proper operation is, of course, willing through the unifying power of love, through which alone can pleasure and delight follow. ${ }^{72}$ God pours into the activity of our will love (amor) and enjoyment (fruitio), through which the mind becomes full of marvellous delight (mira laetitia) ${ }^{73}$ This aspect in the operation of the will is essential for the internal beatitude (beatitudo interior), which is based upon the ability to enjoy God as its object, whereas through contemplation, just as through some first natural instinct, the object of this beatitude is kept in a constant activity of movement. ${ }^{74}$ Octavianus in his reply tries to identify the will with practical knowledge by presenting this argument: if contemplation is only an operation through which the movable object would be kept in the will, it means that any contemplation is already practical, and thus any knowledge (which we have through this contemplation) is practical too, since it is stretched out towards the activity of the will which is a practice. But then, Fridericus should explain how come that so many thinkers (mainly Aristotle and Thomas) preferred speculative sciences. The existence of this kind of speculative knowledge means, according to Octavianus, that there is knowledge which should not be referred to the will as its own end or purpose. ${ }^{75}$ Fridericus' reply makes an interesting point:

71) Ibid., p. 204: "Ipsa igitur praesentia nova nil aliud est quam ipsius obiecti motio: est enim Deus liberum obiectum, potestque inesse, nec tamen movere; inexsistens igitur dum libuerit movebit et videbitur, non movebit et inspicietur minime. Visio igitur ipsa erit operatio intellectus ab ipso moti obiecto. Haec vero operatio est solum qua cognoscitur quid sit ipsum movens obiectum, quale, quantaeque bonitatis, quantae felicitatis, quantae beatitudinis; at viderequemadmodum nec cognoscere-beatitudinem facit beatum neminem."

72) Ibid.: "Data vero eiusmodi cognitione, movetur et ipsa voluntas ab eodem obiecto, ipsaque libere erga id elicit actum volendi sive amoris, et operatur et adhaeret, et coniunctio fit mutua;... non posse ullo pacto voluptatem aut ullam iocunditatem sequi ex operatione intellectus, sed solum habita voluntatis operatione."

73) Ibid., 204-205: "Unde si Deus ipse voluntati nostrae amorem sive sui fruitionem vel quovis alio modo nomines voluntatis actum infunderet, absque eo quod intellectus quidquam—nisi ut prius - videret, iam ipso habito mira quaedam laetitia ipsam perfunderet mentem. At si omnem infundat cognitionem, voluntate nil operante, voluptas aut animi oblectatio sequetur nulla."

74) Ibid., p. 205: "Beatitudo igitur interior in ipsa fruitione erit, in Deo ut obiecto, in contemplatione veluti in quodam naturali praevio, et veluti in eo quo detinetur ipsum beatitudinis obiectum in continuo motionis actu."

75) Ibid.: "Si enim eam ob rem poneretur ut voluntati motivum obiectum detineat, iam practica omnis contemplatio omnisque notitia esset, cum ad voluntatis actum extenderetur, qui est vere praxis. Enimvero, sunt scientiae 'speculativae' dictae, atque hae ab omnibus conceduntur. Non itaque omnis notitia ad voluntatem referetur tamquam sibi bona." Šojat refers to relevant passages in Aristotle and Thomas in the notes. 
Every knowledge and skill strives after some good through the will, as it were, not through the intellect; and thus it has been instituted, and is disposed, towards the good of that, the object of which is the good itself, or a certain disposition of [its] object. ${ }^{76}$

According to Salviati, knowledge (cognitio) and skill (ars) are also "acting" just as if they had a will. Thus he rejects the relation between the operation of the will through love and practical knowledge suggested above. Since these practical sciences are more popular in the common use and have more influence, mankind would love them more. Thus, each man can prefer for himself such science which the will regards as more valuable. Salviati claims that the syllogism: "this science is being loved, the object of this science is being loved, and so this science is practical" is false, since it falsely assumes that any operation of the will is practical. ${ }^{77}$ According to our Franciscan theologian the will is not related to practical knowledge only. A science which is solely practical presents to the will the relevant information with regard to which the will determines what is right or wrong, a good or an evil way of acting by using that goodness which we call moral. ${ }^{78}$ But not everything is of this kind. The operation of the will with regard to this kind of knowledge which is presented by the intellect is called practice. ${ }^{79}$ The implication is that the operation of the will is far beyond practical knowledge. It is related to practical knowledge when in moral decisions the practical data are presented by the intellect to the will in order to reach the right decision. But the will can also act differently, for instance, as we shall shortly see, through love in contemplative life, which brings in theology and the speculative (as opposed to practical) element. Salviati concludes that this volition would be practical when it commands us to do something with

\footnotetext{
76) Ibid.: "Omnis cognitio omnisque ars veluti voluntate—non intellectu—bonum quoddam appetit, ita et ad bonum illius, cuius obiectum est ipsum bonum sive condicio quaedam obiecti, instituta est et ordinatur." We have here of course a clear echo of the opening sentence of the Nicomachean Ethics.

77) Ibid., 205-206: "Quare fit ut illae scientiae potius sint in usu communi, vigoremque obtineant, quas magis genus humanum amet. Et quisque eam sibi praeficit quam voluntas gratiorem habet. Nulla itaque consequentia est: 'amatur haec scientia, huiusque scientiae obiectum, est igitur practica'; ponit enim falso ut quaelibet voluntatis operatio sit praxis." Notice that usus communis and genus humanum are contrasted to omnes conceduntur in Octavianus' argument.

78) Ibid., p. 206: "Ea namque solum scientia est practica, quae ostendit voluntati ea ipsa circa quae voluntas poterit et recte et non recte agere et esse bona aut non bona ea bonitate quam 'moralem' appellamus."

79) Ibid.: "At non omnia sunt talia. Et voluntatis operatio circa eiusmodi, ab intellectu ostensa, praxis dici solet."
} 
regard to external things. He follows Franciscus Baconis who, according to Salviati, included in practical volition also a mere possibility or a mere intention to effect external things, or a need to effect them. ${ }^{80}$

What, then, about speculative sciences? It is possible to love the knowledge of the movement of the stars, to know the reasons of natural things, which would be knowing the essence of something which exists. All these sciences are not practical and do not deal with what is related to the practice of the will; but we still find in them activity or love. ${ }^{81}$ Here we meet again the sensitivity of Salviati regarding the common use of terms: he claims that not everyone distinguishes in common speech or discourse (communis locutio) between contemplation and activity, but rather, this distinction is unique only to the school of Franciscus Baconis. ${ }^{82}$ Salviati is not using any other authority to establish his critique of Baconis and his school, but only the common way of speech: dicimus enim communiter. This common use, in this case, seems sufficient for a philosophical argumentation and it may represent an important shift in both style and focus of later scholastic thinkers, who try to be more sensitive to the common use of language (and more communicative also with regard to the new humanist readership), and thus less technical, in dealing with practical as well as with speculative problems. ${ }^{83}$

With regard to this distinction between contemplation and activity, Salviati argues that we do commonly say that those who live an active life act (agunt) or use (faciunt) prudence or skill. But we also do not say that those who use

80) Ibid.: "Concludamus iam ut omnis ea volitio sit practica qua imperante quidquam ad extra efficimus, atque omnis ea-secundum Doctorem Sublimem-quae, etsi nil ad extra efficiat, efficeret tamen si vel posset, vel si efficere opus esset (veluti is qui liberalitatis officium exercere vellet, nec tamen potest; et si qui Deum amat et vult, promptus ad exsequendum omnia quae suo pro amore oportet)." It is important to notice how amor is used in the example, with regard to God. Šojat could not find the relevant passage in Franciscus Baconis.

81) Ibid.: "Amare vero siderum cursus notitiam, rerum naturalium cognoscere causas, quid sit entis quiditas: hae neque practicae sunt, neque erga ea fit voluntatis praxis; fit tamen actus sive amor."

82) Ibid.: "Non tamen ita communi locutione contemplationem ab actione separant omnes: sed schola tantum Sublimium."

83) This point, however, can be related to the discussions concerning common principles, communia, discussed in the context of medieval compendia in Hoenen, 'Late Medieval Schools...' 341-345. See also the remarks on conventional language and ordinary usage of terms in Lodi Nauta, 'William of Ockham and Lorenzo Valla: False Friends. Semantics and Ontological Reduction', in Renaissance Quarterly 56 (2003), 613-651; see especially 624-625, 630-634, 636, 641-642, 645-648. 
contemplation and live contemplative life (otiosam vitam degant) like the monks, would not supremely love and abundantly use caritas: rather, we say that they are not exercising in their contemplative life justice, generosity, and common skills. ${ }^{84}$ Apparently love, which is the operation of the will, plays an important role also in the contemplative life; in other words, the will is not related only to moral concerns in active life, it is deeply related (through amor and caritas) also to contemplative life, to theology and to speculative sciences. This is why one should not distinguish contemplation from any kind of activity: contemplation is not related to actions with regard to practical decisions or politics, but it is still related to activities like love.

Salviati mentions Augustine's famous distinction between action and contemplation: according to Augustine, Martha and Peter represent active life while Mary and John represent contemplative life. ${ }^{85}$ But immediately after this Salviati indicates that according to Scotus Mary and John represent the more important part of active life. ${ }^{86}$ This interpretation represents a tendency for greater appreciation of the active life, or at least for an extension of its range. ${ }^{87}$ It is striking that Šojat, the editor of Salviati's text, could not find this

84) Salviati, Fridericus 206-207: "Dicimus enim communiter, activam vitam eos agere qui prudentia sive arte quidquam agunt sive faciunt (ut de virtutibus ipsis illiberalibusque artibus patet); contemplari vero eos qui otiosam vitam degant (ut monachos contemplativos) dicimus, non quia non summe ament et caritate abundent, sed quia neque iustitiam neque liberalitatem neque artes communes exercent."

85) Ibid., p. 207: "Eo modo Augustinus quoque ipse actionem a contemplatione distinxit: vocat enim Marthae vitam quae satagebat circa frequens ministerium, 'actionem',-Mariae vero, quae audiebat verbum dulcissimum, 'contemplationem'; et Ioannem Zebedaeum, qui interiore homine laborabat, vitam contemplativam significare ait,-Petrum, qui exercitio corporali multa faciebat, activam.” Šojat gives in the notes the relevant references and passages from Scripture and Augustine.

86) Ibid., p. 208: "At ex opinione Subtilis Doctoris Maria et Ioannes dicendus est nobiliorem partem vitae activae tenuisse."

87) We can find the same tendency with the same biblical theme in one of Savonarola's sermons delivered on March 18, 1496; see: Girolamo Savonarola, Prediche Italiane Ai Fiorentini, 4 vols. (Perugia-Venezia and Firenze, 1930-1935), eds. Francesco Cognasso (vols. 1 and 2) and Roberto Palmarocchi (vols. 3a and 3b), vol. 3b, p. 173: "Marta adunque e Maria, che significano e li proficienti e li perfetti della vita attiva e contemplativa..." Perfection is related not only to contemplative life but also to active life. The sick Lazarus signifies the better part of the Florentines (ibid., p. 177) and he is being helped by both Martha and Mary, active and contemplative life. The connection between active and contemplative life is described by Savonarola in another sermon (ibid., 109) as an important part of the Scriptures. In fact, active and contemplative life complement one another and the preacher can ask his audience (ibid., vol. 3a, p. 53) to assist one another in both ways. 
reference in Scotus. This might be an original interpretation of Salviati under the increasing influence of the humanists in fifteenth-century Italy, but also under the influence of some interesting changes and developments in the later scholastic philosophical discourse. We know, for instance, that also in the case of Adrian of Utrecht (1459-1523), a leading and influential figure in the academic and intellectual life in Louvain and in the Low Countries, in the last two decades of the fifteenth century and the first decade of the sixteenth century, who later became pope, we can find a similar tendency in which the active life and practical questions became the arena and basis for moral discussions of casus conscientiae in the Quodlibetal disputations. ${ }^{88}$

In his conclusion to chapter 20 Salviati first reconciles the opinions of Aristotle, Thomas, and Augustine, with regard to contemplation, clearly leaving out of this reconciliation the "opinion of Scotus" which he has just mentioned. ${ }^{89}$ Then, he claims, it is right to say that the contemplative life represents our happiness (felicitas nostra), since the will is in accord with its object: the will drives the intellect to be occupied with the operation of contemplation. ${ }^{90}$ The activity of both the will and the intellect necessarily come together towards contemplation; but there is an essential difference between them: while the activity of the will is what causes union (coniungens), that of the intellect is only being united (coniunctus). The real or true beatitude (vera beatitudo, as distinct from the above-mentioned felicitas nostra), consists of that operation which unites by its own virtue or power (sui gratia), whereas the intellect is dependent on, and controlled by, some other power. ${ }^{91}$ The true beatitude is thus found in the unifying activity of the will and not in contemplation or in

\footnotetext{
88) See the detailed discussion with further references in M.W.F. Stone, 'Adrian of Utrecht and the University of Leuven: Theology and the Discussion of Moral Problems in the Late Fifteenth Century', in Traditio 61 (2006), 247-287. Another example of this development can be found in the thought of the Florentine archbishop Antoninus Pierozzi (1389-1459). On Antoninus see especially D. Peterson, Archbishop Antoninus: Florence and the Church in the Earlier Fifteenth Century (Ph.D. dissertation, Cornell University 1985); Peter Francis Howard, Beyond the Written Word-Preaching and Theology in the Florence of Archbishop Antoninus 1427-1459 (Firenze, 1995); and M.W.F. Stone, ‘The Origins of Probabilism' 143-148.

89) Salviati, Fridericus p. 208: "Non abs re itaque dicere possumus ut Aristoteles ipse, sanctusque Thomas contemplationem ita acceperint veluti et Augustinus."

90) Ibid.: "Et eiusmodi vita contemplativa felicitas nostra recte dicenda est. Convenit enim voluntas cum suo obiecto; intellectum et in operatione contemplattionis assiduum reddit."

91) Ibid.: "Uterque enim actus ad contemplationem necessario concurrit: voluntatis ut coniungentis, intellectus ut coniuncti. Sed in ea operatione quae coniungit sui gratia, vera beatitudo est,-—in intellectu ut propter aliud et tamquam in ministrante."
} 
contemplative life as such. As we have seen, this activity is independent and free, and to some extent it breaks the traditional distinction between active and contemplative life since it is dominant in both, either through its ability to make the right decision in practical matters of ethics, or through its unifying power with regard to the supreme good or God, in speculative matters of theology. From this point of view the difference between "Scotus" nobilior pars vitae activae and the more accepted opinion regarding contemplatio can be seen as only semantic.

The next chapter, number 21 , is in fact the last one in the dialogue, since the three closing chapters $(22,23,24),{ }^{92}$ contain a summary of the main arguments in the form of responses to the proposed arguments presented by Octavianus in chapters 3-7.93 These closing chapters were written according to the specific request of Octavianus from Salviati himself (though he promises that both he and Fridericus will help him). ${ }^{94}$ And so, chapter 21 contains Octavianus' praises of Fridericus, the duke of Urbino, and as expected, it is full of rhetorical gestures. ${ }^{95}$ Moreover, it contains not only obvious comparisons between Fridericus and Alexander the Great or Julius Caesar, with an emphasis on Caesar's eloquence and on Alexander's famous relation to Aristotle under the image of the philosopher-king, but also, and first of all, a comparison with the mythological figure of Hermes Trismegistus. ${ }^{96}$ This is of course another important humanistic feature. The figure of Hermes or Mercurius, a Greek version of the Egyptian god Thoth, became a source of inspiration for the idea of the ancient wisdom in the Florentine circle of Ficino during the 1460s and 1470s. A manuscript containing some parts of the Corpus Hermeticum was

\footnotetext{
92) Ibid., 210-219.

93) Ibid., 144-157.

94) Ibid., p. 210: “Tuque, Georgi Benigne, haec quae dicta sunt et menti et litteris manda. Iuvabo et ipse, iuvabit et Lazarus noster, si quid forsan tibi excidisset."

95) E.g., ibid., p. 209: "Habuit Montefeltrea haec domus imperatores atque duces, ipsius quidem militaris rei et gloria et maxima laude decoratos. Sed qui tanta eloquentia, omni sapientia referta simul et armis, valuerit, id neque e Graecis ulli neque e Romanis ipsis umquam assequi fas fuit." 96) Ibid.: "Trismegistum illum, quem et regem magnum et philosophum ferunt, forsan tibi conferemus? At quae rudibus illis annis philosophiae praestantia? Quaeve fictilis paucisque contenti regni gloria fuisse potuit? Fuit Caesar ipse eloquentiae splendore clarus. Sed quae sibi immortalium divinarum rerum peritia? Alexandrum quoque illum Macedonem hausisse quidem plurimum ex Aristotele philosophiam constat, sed ei omnia quam raptissime cum vita pariter ex oculis hominum defluxerunt." With regard to Alexander, Šojat gives in the notes the relevant passage from Plutarch, in the Latin translation of Guarino Veronese. Once again we see how Salviati combines humanistic and scholastic traditions.
} 
given to Ficino by Cosimo in 1462, and the humanist philosopher translated it by 1463 . It went to print twice: in 1471 , and in an improved version in 1472. Hermes was then included among Ficino's prisci theologi, an essential element in Ficino's own programme of spiritual renovation presented in his De Christiana religione and in his Theologia platonica, as well as in other minor writings and letters. These Hermetic writings, which were soon translated into vernacular languages and printed many times, had enormous influence during the course of the next centuries upon many European intellectuals. ${ }^{97}$

The mention of Hermes by Salviati should not be regarded as rhetorical only in the light of his later works and intellectual development, in which we find the increasing influence of spiritual mysticism, originating in at least three direct sources: the Franciscan prophetic tradition of the Apocalypsis nova attributed to beato Amadeo (João da Silva y Menezes) and his followers; Ficino's Neoplatonic project of Christian renovation, an echo of Cardinal Bessarion's earlier influence; and the influential Dominican preacher and prophet Savonarola and the movement of the piagnoni. ${ }^{98}$ Such later developments can be found already in this early work of Salviati on the will, in which, as we have seen, amor's unifying quality was assigned an important role, through which the will operates.

All these sources of influence, although they had their deep roots in the pagan and Christian Neoplatonism and mysticism of late antiquity, or in the medieval apocalyptic and prophetic movements, are still also a unique product of fifteenth-century Italy, mainly of fifteenth-century humanism and scholasticism. We can say that 'Scotism' or the Scotistic school as reflected in the works and intellectual development of Salviati is merely a general title for many different trends of thought, some of which are quite far from Scotus or the Scotists in the fourteenth century. 'Scotism' in this context means a very open philosophical and cultural phenomenon; it is related to many different traditions and sources, a very lively intellectual movement which embraced much of the Zeitgeist. Members in this school still kept some unique features

97) On this see e.g., the classical studies by Frances A. Yates, Giordano Bruno and the Hermetic Tradition (London, 1964), especially the first four chapters; and by D.P. Walker, The Ancient Theology: Studies in Christian Platonism from the Fifteenth to the Eighteenth Century (London, 1972), especially the first two chapters. A good account of these matters with further references can be found in Brian P. Copenhaver and Charles B. Schmitt, Renaissance Philosophy (Oxford, 1992), 146-148.

98) These later tendencies in Salviati's works are discussed at length with further references in Vasoli's Profezia e ragione, 17-120. 
with regard to Scotus or to more traditional version of Scotism, such as the obsession with the will (beyond using the name of Scotus and being regarded by themselves and by others as Scotists), but they included many different later developments, as well as taking into account many aspects and authors in the rich scholastic tradition up to the fifteenth century, in what in fact was quite an original and independent school of thought. In such a context it was possible to regard the Franciscan prophet beato Amadeo or the Dominican piagnone Domenico Benivieni as Scotists, to write a Scotistic commentary on one of Lorenzo de' Medici's sonnets, and to marry Platonism to Scotism. ${ }^{99}$

Salviati, who, as we have seen, should be regarded as princeps voluntatis, represents in his discussion the two great contemporary traditions: the scholastic and the humanistic. ${ }^{100}$ Thus, he was the perfect choice to protect Ficino against the "wolves" (i.e., some critics in the Curia of Ficino's approach to astrology as discussed in his De vita) in Rome in 1489. ${ }^{101}$ But in fact, Ficino "would have needed" his help earlier, in his dispute with Lorenzo de' Medici held in 1474 regarding the will and the intellect, against the critique of Vincenzo Bandello. Ficino was not attcked by a wolf then, but he was sharply criticized by a Dominican friar who was a prominent scholastic philosopher. Many answers to this critique, and mainly a developed theory of the will as the dominant power in the human soul, as well as of its importance in ethics and in theology, are presented in Salviati's discussion. As we have seen from the

99) On beato Amadeo as a Scotist see Vasoli, Profezia e ragione, especially 88-89, 93; on Domenico Benivieni's Scotism in Ficino's circle see ibid., n. 54 on p. 42 and context; on the relation between Platonism and Scotism see: ibid., especially 102-106; for Salviati's Scotist commentary to Lorenzo's poem see n. 4 above.

100) Though he was obviously a scholastic thinker, a product of the later scholastic philosophy, Salviati's relations with the humanist culture had very deep roots, as can be seen also in his critique of the misrepresentations of the poets of amor as puer nudus et caecus, caused by their improbity, since they do not know that amor is in fact subjected to the will; see Salviati, Fridericus p. 211: "Pingunt autem poetae amorem puerum nudum et caecum, ob eorum improbitatem voluntatis qui nolunt divinae superiorumque voluntati subdi..." On this well-known Renaissance theme both in literature and art, see Edgar Wind, Pagan Mysteries in the Renaissance (New Haven, 1958; revised edition, Oxford, 1980), especially chapter four.

101) On this affair see Ficino's letter in his Opera mnia... vol. 1, 574-575; this letter was edited and translated in Marsilio Ficino, Three Books On Life, eds. Carol V. Kaske and John R. Clarck (New York, 1989), 402-405. More details on this affair, with further references, can be found in Jill Kraye, 'Ficino in the Firing Line: A Renaissance Neoplatonist and his Critics', in Michael J.B. Allen and Valery Rees with Martin Davies (eds.), Marsilio Ficino: His Theology, His Philosophy, His Legacy (Leiden, 2002), 377-397; see especially 377-378. This letter is also mentioned in Vasoli, Profezia e ragione, p. 42, n. 55. 
dramatic dynamic of the dialogue, Salviati (mainly through Octavianus' critical remarks and questions) is quite aware of the fact that he presents a theory of the will which is quite new and different from what can be found in Aristotle, Augustine, and Thomas. This is another case of the way in which scholasticism and humanism in fifteenth-century Italy influence and condition one another. Yet we must remember that many of Salviati's writings are still available only in manuscript form, and that most of his writings have not been studied with sufficient scholarly attention and empathy for their own merits. I hope that the present discussion has shown that this task is indeed a desideratum for the students of both scholasticism and humanism in the fifteenth century. ${ }^{102}$

102) I would like thank Prof. Martin W.F. Stone and the editors of Vivarium for some very useful remarks and suggestions. 
Copyright of Vivarium is the property of Brill Academic Publishers and its content may not be copied or emailed to multiple sites or posted to a listserv without the copyright holder's express written permission. However, users may print, download, or email articles for individual use. 